medRxiv preprint doi: https://doi.org/10.1101/2021.02.04.21251153; this version posted February 8, 2021. The copyright holder for this preprint (which was not certified by peer review) is the author/funder, who has granted medRxiv a license to display the preprint in perpetuity.

All rights reserved. No reuse allowed without permission.

\title{
Ventilation rate assessment by carbon dioxide levels in dental treatment rooms
}

\author{
Qirong Huang, Tamer Marzouk, Razvan Cirligeanu, Hans Malmstrom, Eli Eliav, Yan-Fang Ren*
}

Drs. Huang, Marzouk and Cirligeanu are research fellows and residents in Advanced Education in General Dentistry; Dr. Malmstrom is Professor and Chair, Dept. of General Dentistry; Dr. Eliav is Professor and Director, Eastman Institute for Oral Health; Dr. Ren is Professor and Director, Howitt Dental Urgent Care at Eastman Institute for Oral Health, University of Rochester Medical Center. ${ }^{*}$ Correspondence to Dr. Ren Yanfang ren@urmc.rochester.edu

\begin{abstract}
:
Objectives: The purpose of the present study was to monitor and evaluate $\mathrm{CO}_{2}$ levels in dental operatories using a consumer-grade $\mathrm{CO}_{2}$ sensor and determine the utility and accuracy of various methods using $\mathrm{CO}_{2}$ levels to assess ventilation rate in dental clinics. We aim to find a practical tool for dental practitioners to conveniently and accurately monitor $\mathrm{CO}_{2}$ levels and assess the ventilation rates in their office in order to devise a pragmatic and effective strategy for ventilation improvement in their work environment.
\end{abstract}

Methods: Mechanical ventilation rate in air change per hour $\left(\mathrm{ACH}_{\mathrm{VENT}}\right)$ of 10 dental operatories was first measured with an air velocity sensor and air flow balancing hood. $\mathrm{CO}_{2}$ levels were measured in these rooms to analyze the effects of ventilation rate and number of persons in the room on $\mathrm{CO}_{2}$ accumulation. Ventilation rates were estimated using natural steady state $\mathrm{CO}_{2}$ levels during dental treatments and experimental $\mathrm{CO}_{2}$ concentration decays by dry ice or mixing baking soda and vinegar. We compared the differences and assessed the correlations between $\mathrm{ACH}_{\text {VENT }}$ and ventilation rates estimated by steady states $\mathrm{CO}_{2}$ model with low $(0.3 \mathrm{~L} / \mathrm{min}$, $\left.\mathrm{ACH}_{\mathrm{ss} 30}\right)$ or high $\left(0.46 \mathrm{~L} / \mathrm{min}, \mathrm{ACH}_{\mathrm{sS} 46}\right) \mathrm{CO}_{2}$ generation rates, by $\mathrm{CO}_{2}$ decay constants using dry ice $\left(\mathrm{ACH}_{\mathrm{DI}}\right)$ or baking soda $\left(\mathrm{ACH}_{\mathrm{BV}}\right)$, and by time needed to remove $63 \%$ of excess $\mathrm{CO}_{2}$ generated by dry ice $\left(\mathrm{ACH}_{\mathrm{DI} 63 \%}\right)$ or baking soda $\left(\mathrm{ACH}_{\mathrm{BV} 63 \%}\right)$.

Results: $A C H_{V E N T}$ varied from 3.9 to 35.0 with a mean of $13.2( \pm 10.6)$ in the 10 dental operatories. $\mathrm{CO}_{2}$ accumulation occurred in rooms with low ventilation $\left(\mathrm{ACH}_{\mathrm{VENT}} \leq 6\right)$ and more persons $(n>3)$ but not in those with higher ventilation and less persons. $\mathrm{ACH}_{\mathrm{SS} 30}$ and $\mathrm{ACH}_{\mathrm{SS} 46}$ correlated well with $\mathrm{ACH}_{\mathrm{VENT}}(\mathrm{r}=0.83, \mathrm{p}=0.003)$, but $\mathrm{ACH}_{\mathrm{SS} 30}$ was more accurate for rooms with low $\mathrm{ACH}_{\text {VENT. }}$. Ventilation rates could be reliably estimated using $\mathrm{CO}_{2}$ released from dry ice or baking soda. $\mathrm{ACH}_{\mathrm{VENT}}$ was highly correlated with $\mathrm{ACH}_{\mathrm{DI}}(\mathrm{r}=0.99), \mathrm{ACH}_{\mathrm{BV}}(\mathrm{r}=0.98)$, $\mathrm{ACH}_{\mathrm{D} 163 \%}(\mathrm{r}=0.98)$, and $\mathrm{ACH}_{\mathrm{BV} 63 \%}(\mathrm{r}=0.98)$. There were no statistically significant differences between $\mathrm{ACH}_{\mathrm{VENT}}$ and $\mathrm{ACH}_{\mathrm{DI} 63 \%}$ or $\mathrm{ACH}_{\mathrm{BV} 63 \%}$.

Conclusions: Dental operatories with low ventilation rates and overcrowding facilitate $\mathrm{CO}_{2}$ accumulations. Ventilation rates could be reliably calculated by observing the changes in $\mathrm{CO}_{2}$ levels after a simple mixing of household baking soda and vinegar in dental settings. Time needed to remove $63 \%$ of excess $\mathrm{CO}_{2}$ generated by baking soda could be used to accurately assess the ventilation rates using a consumer-grade $\mathrm{CO}_{2}$ sensor and a basic calculator.

Key words: ventilation rate, carbon dioxide, baking soda, dentistry, COVID-19

NOTE: This preprint reports new research that has not been certified by peer review and should not be used to guide clinical practice. 
medRxiv preprint doi: https://doi.org/10.1101/2021.02.04.21251153; this version posted February 8, 2021. The copyright holder for this preprint (which was not certified by peer review) is the author/funder, who has granted medRxiv a license to display the preprint in perpetuity.

All rights reserved. No reuse allowed without permission.

\section{Introduction:}

Risks of disease transmission in healthcare settings during infectious disease pandemics have consistently challenged dental care professionals (DCPs) in their efforts to maintain a safe environment for their staffs and patients. DCPs have gained tremendous experiences in infection control from the ongoing HIVIAIDS pandemic by implementing universal or standard precautions against contact and droplet transmissions, but we are less confident in dealing with an infectious respiratory disease that may be transmitted through aerosol particles emitted by patients who have no overt symptoms. With mounting evidence that COVID-19 is transmissible through aerosols in an indoor environment [1, 2], additional preventive measures beyond the standard care using personal protective equipment (PPE) are essential to minimize risks and alleviate anxieties experienced by staff and patients due to uncertainties associated with a novel infectious respiratory disease pandemic.

Engineering controls through mechanical ventilation are important mechanisms to reduce the risks of airborne disease transmission in an indoor environment such as the dental offices.

Though CDC recommends improving ventilation and air filtration in its guidance for dental settings during the COVID-19 pandemic [3], few information is available on how to assess the ventilation condition and what measures to take to achieve more effective engineering control of disease transmission in dental offices.

Carbon dioxide $\left(\mathrm{CO}_{2}\right)$ level is an important indicator of ventilation in occupied indoor environments. $\mathrm{CO}_{2}$ is a byproduct of human metabolism and exists in high levels in exhaled air. Atmospheric $\mathrm{CO}_{2}$ level is at approximately 400 parts per million (ppm) in most outdoor environments, but $\mathrm{CO}_{2}$ in human exhaled air reaches on average $40,000 \mathrm{ppm}$ in concentration [4]. $\mathrm{CO}_{2}$ levels is therefore often used as a proxy for indoor air quality as well as a risk marker for transmission of airborne diseases since it is inert, its indoor emission source (human) is known, and its measurement is inexpensive and accurate [5]). Accumulation of $\mathrm{CO}_{2}$ may occur in indoor spaces with poor ventilation and overcrowding, and consequentially increase the risks of disease transmission, which is of particular significance under the current COVID-19 pandemic. High levels of $\mathrm{CO}_{2}$ in indoor environments have been associated with the transmission of infectious respiratory diseases such as tuberculosis, influenza and rhinovirus infections [6-8]. Indoor $\mathrm{CO}_{2}$ levels have therefore been widely used to model the risks of airborne infectious disease transmission $[4,9,10]$, including that of coronavirus infection transmission in dental offices [11]. 
medRxiv preprint doi: https://doi.org/10.1101/2021.02.04.21251153; this version posted February 8, 2021. The copyright holder for this preprint (which was not certified by peer review) is the author/funder, who has granted medRxiv a license to display the preprint in perpetuity.

All rights reserved. No reuse allowed without permission.

$\mathrm{CO}_{2}$ levels is directly associated with ventilation rate in an occupied space. A clinical space with good ventilation should have a $\mathrm{CO}_{2}$ level close to that of outside air at approximately $400 \mathrm{ppm}$ in most areas [4, 12]. Higher indoor $\mathrm{CO}_{2}$ levels indicate poor ventilation, accumulation of exhaled air, and increase in the fraction of "rebreathed air" or "shared air" in the indoor environment, which is proven to be a risk factor for transmissions of respiratory infectious diseases $[4,7,8$, 10]. $\mathrm{CO}_{2}$ levels have been used to estimate ventilation rates in dental offices through mathematic modeling [13-15]. Godwin and colleagues reported that the ventilation rate was 1.12 air change per hour ( $\mathrm{ACH}$ ) in a typical dental clinic in the US [13], and Helmis and colleagues found that it was on average $5 \mathrm{ACH}$ in a dental school clinic in Greece where the doors and windows were opened for cross ventilation [15]. Both studies used natural build-up of $\mathrm{CO}_{2}$ levels in the dental clinic to estimate the ventilation rate through mathematic models, but none of them actually verified the ventilation estimates using conventional methodologies such as a highprecision airflow sensor [16]. It is not known if these estimates were accurate as both methods require mathematical modeling based on several assumptions related to $\mathrm{CO}_{2}$ generation, buildup and dispersion over a relatively lengthy period of time, which may result in erroneous estimates if any of the assumed conditions are not met [5]. A simpler and more reliable method is needed if $\mathrm{CO}_{2}$ level is to be used by dental practitioners to assess the ventilation rate of their treatment rooms.

The purpose of the present study was two-folds: 1) to monitor and evaluate $\mathrm{CO}_{2}$ level and its associated factors in dental operatories using a consumer-grade $\mathrm{CO}_{2}$ sensor, and 2) to determine the utility and accuracy of various methods that use $\mathrm{CO}_{2}$ levels to assess ventilation rate in dental clinics. Our aim was to find a practical tool that will enable all dental practitioners to conveniently and accurately monitor $\mathrm{CO}_{2}$ levels and assess the ventilation rates in their treatment rooms in order to devise a pragmatic and effective strategy for ventilation improvement in their work environment.

\section{Methods:}

Study settings: We conducted the $\mathrm{CO}_{2}$ concentration and ventilation rate assessments in 10 treatment rooms ranging from 667 to 1221 cubic feet $\left(\mathrm{ft}^{3}\right)$ in sizes. Mechanical ventilations of the treatment rooms are provided by three separate air handlers that drew 30\%, 50\% and 50\% outside air to the ventilation systems. The outside air percentage were later increased to $60 \%$ for all three air handlers as part of our institutional response to COVID-19.

Determining room airflow and mechanical ventilation rates: The mechanical ventilation of the 10 selected dental treatment rooms was measured with an air velocity sensor integrated in an air 
medRxiv preprint doi: https://doi.org/10.1101/2021.02.04.21251153; this version posted February 8, 2021. The copyright holder for this preprint (which was not certified by peer review) is the author/funder, who has granted medRxiv a license to display the preprint in perpetuity.

All rights reserved. No reuse allowed without permission.

flow balancing hood (ADM-850L Airdata Multimeter with CFM-850L FlowHood, Shortridge Instruments Inc., Scottsdale, AZ) as described elsewhere [17]. Briefly, the volumetric airflow rates of the dental treatment rooms were measured in cubic feet per minute (CFM, or $\mathrm{ft}^{3} / \mathrm{min}$ ) at both the air supply inlets and air exhaust returns using the air flow balancing hood. The mechanical ventilation rates of each space in number of $\mathrm{ACH}$ was calculated based on supply and exhaust airflow rates for each room. The larger value between $\mathrm{ACH}$ from supply air and $\mathrm{ACH}$ from return air was used as the room's mechanical ventilation rate (ACHVENT $)$ [18].

Assessing $\mathrm{CO}_{2}$ levels during dental treatment procedures: We measured $\mathrm{CO}_{2}$ levels in two dental treatment rooms when dental procedures were performed. The two rooms represented two extremes in ventilation rates, with one at the lowest at $3.9 \mathrm{ACH}$, and the other at the highest at $35 \mathrm{ACH}$. The number of persons in the rooms were recorded in real time when a person was entering and leaving the room. One of the two rooms were used for dental implant therapy and may often have more than one graduate students observing the procedures in addition to the treating dentist, the dental assistant and the patient in the room.

24-hour Continuous monitoring $\mathrm{CO}_{2}$ in dental treatment rooms: To further explore the dynamics of $\mathrm{CO}_{2}$ levels in dental treatment rooms throughout the work day and assess of accuracies of the steady state models of $\mathrm{CO}_{2}$ for ventilation assessments, we continuously measured the $\mathrm{CO}_{2}$ levels in the 10 selected dental treatment rooms for 24 hours and recorded the procedures performed and number of persons in the room.

Assessing ventilate rate by natural $\mathrm{CO}_{2}$ level modeling in dental treatment rooms: We used the steady state model described by Batterman [5] to calculate the $\mathrm{ACH}$ of the treatment rooms and compared the outcomes with $\mathrm{ACH}_{\mathrm{VENT}}$ determined by mechanical ventilation.

The steady state air change rate $\left(\mathrm{ACH}_{\mathrm{Ss}}\right)$ is calculated as follows [5]:

$$
\mathrm{ACH}_{\mathrm{ss}}=6 \times 10^{4} \mathrm{n} \mathrm{Gp} /\left[\mathrm{V}\left(\mathrm{C}_{\mathrm{ss}}-\mathrm{C}_{\mathrm{R}}\right)\right]
$$

Where $\mathrm{n}=$ number of persons in the room; $\mathrm{G}_{\mathrm{P}}=$ average $\mathrm{CO}_{2}$ generation rate; $\mathrm{V}=$ volume of the room in cubic meters $\left(\mathrm{m}^{3}\right)$; $\mathrm{Css}=$ steady state indoor $\mathrm{CO}_{2}$ level in ppm; and $\mathrm{C}_{\mathrm{R}}=\mathrm{CO}_{2}$ level in outdoor air in ppm.

The $\mathrm{CO}_{2}$ generation rate $\mathrm{G}_{\mathrm{p}}$ is affected by many factors and may vary by human activity, physical size, sex and race $[19,20]$. $\mathrm{G}_{p}$ values of $0.46 \mathrm{~L} / \mathrm{min}$ and $0.30 \mathrm{~L} / \mathrm{min}$ have been used in previous studies to represent $\mathrm{CO}_{2}$ generation by moderately active adults [5], [13]). As the $\mathrm{CO}_{2}$ generation rates and activity levels by dental care providers and their patients are unknown and may not be constant, we decided to use both values to calculate the steady state air change 
medRxiv preprint doi: https://doi.org/10.1101/2021.02.04.21251153; this version posted February 8, 2021. The copyright holder for this preprint (which was not certified by peer review) is the author/funder, who has granted medRxiv a license to display the preprint in perpetuity.

All rights reserved. No reuse allowed without permission.

rate $\mathrm{ACH}_{\mathrm{SS}}$ and assess the correlations between $\mathrm{ACH}_{\mathrm{SS}}$ and $A C \mathrm{H}_{\mathrm{VENT}}$ at two GP levels $(0.46$ and $0.30 \mathrm{~L} / \mathrm{min}$, respectively).

Assessing ventilation rates by $\mathrm{CO}_{2}$ decays using dry ice: Ventilation rates were also measured in the 10 dental treatment rooms using the $\mathrm{CO}_{2}$ decay method [5]. Outside air $\mathrm{CO}_{2}$ level was first measured for 5 minutes near the air intake of the ventilation system outside the building before each experiment. To raise the peak $\mathrm{CO}_{2}$ levels inside the dental treatment rooms to approximately $2000 \mathrm{ppm}, 250 \mathrm{~g}$ of dry ice were placed in a water bath and left in the room for two minutes. A small oscillating fan was used to keep the $\mathrm{CO}_{2}$ well mixed in the room. $\mathrm{CO}_{2}$ level was then measured at one-minute interval using an Aranet4 $\mathrm{CO}_{2}$ sensor (range 0-9999ppm, accuracy \pm 50 ppm, SAF Tehnika, Riga, Latvia) for up two hours. The ventilation rate by $\mathrm{CO}_{2}$ clearance using dry ice $\left(\mathrm{ACH}_{\mathrm{DI}}\right)$ were determined as described by Batterman [5] using the $\mathrm{CO}_{2}$ concentration decays :

$$
A C H_{D I}=1 / \Delta t \ln \left[\left(C_{1}-C_{R}\right) /\left(C_{0}-C_{R}\right)\right]
$$

where $\Delta \mathrm{t}=$ period between measurements; $\mathrm{C}_{0}$ and $\mathrm{C}_{1}=\mathrm{CO}_{2}$ levels measured at the beginning and the end of the decay period (ppm), and $\mathrm{C}_{\mathrm{R}}=\mathrm{CO}_{2}$ level in outdoor air (ppm).

The consumer-grade Aranet4 $\mathrm{CO}_{2}$ sensor used in the current study was purchased at amazon.com in the US. It was recommended by the Federation of European Heating, Ventilation and Air Conditioning Associations (REHVA) for monitoring $\mathrm{CO}_{2}$ levels in schools during the COVID-19 pandemic [21], and was found to be comparable to a research-grade LI$\mathrm{COR} \mathrm{CO}_{2}$ sensor in accuracy and suitable for the time-response assessment in this study [22].

Assessing ventilation rates by $\mathrm{CO}_{2}$ decays using baking soda: Considering that dental practitioners in private practices may not have ready access to dry ice, we developed a method to rapidly generate $\mathrm{CO}_{2}$ in dental treatment rooms using household baking soda (Arm\& Hammer Pure baking soda, Church \& Dwight Co., Inc., Ewing, NJ, USA) and vinegar (Heinz all-natural distilled white vinegar, Pittsburgh, PA, USA). Mixing baking soda $\left(\mathrm{NaHCO}_{3}\right)$ with vinegar containing $5 \%$ acetic acid $\left(\mathrm{CH}_{3} \mathrm{COOH}\right)$ will generate $\mathrm{CO}_{2}$ as follows:

$$
\mathrm{NaHCO}_{3}+\mathrm{CH}_{3} \mathrm{COOH} \rightarrow \mathrm{CH}_{3} \mathrm{COONa}+\mathrm{H}_{2} \mathrm{O}+\mathrm{CO}_{2}
$$

We tested peak $\mathrm{CO}_{2}$ values in the 10 treatment rooms using a weight $(\mathrm{g})$ :volume $(\mathrm{ml})$ ratio of $1: 15$ based on the molar masses of the reagents. We aimed at a peak level range of 1500 to 2000 ppm in rooms with various mechanical ventilation rates and with doors closed. We determined that adding about $125 \mathrm{~g}$ of baking soda (approximately $3 / 5$ cup measure) to $1893 \mathrm{ml}$ (a $64-\mathrm{oz}$ bottle) of vinegar containing $5 \%$ acetic acid will elevate the $\mathrm{CO}_{2}$ level in a typical dental 
medRxiv preprint doi: https://doi.org/10.1101/2021.02.04.21251153; this version posted February 8, 2021. The copyright holder for this preprint (which was not certified by peer review) is the author/funder, who has granted medRxiv a license to display the preprint in perpetuity.

All rights reserved. No reuse allowed without permission.

treatment room (10 $\times 11 \mathrm{ft}$ in area, $8 \mathrm{ft}$ in ceiling height, or $880 \mathrm{ft}^{3}$ in volume) with a moderate ventilation rate $\left(\mathrm{ACH}_{\mathrm{VENT}}=4\right)$ to above $1500 \mathrm{ppm}$. For rooms that are significantly larger or having very high ventilation rates, one full cup measure (about 8 oz or 227g) of baking soda may be used with $3785 \mathrm{ml}$ (a one-gallon jar) of vinegar containing 5\% acetic acid.

Before the baking soda experiment, outdoor $\mathrm{CO}_{2}$ level was first measured for 5 minutes near the air intake of the ventilation system outside the building. To generate $\mathrm{CO}_{2}$ inside the dental treatment rooms, we first poured vinegar into a large container and added the baking soda powder. The mixture was vigorously shaken or stirred with a large spatula for two minutes and then removed from the room. A small oscillating fan was used to keep the $\mathrm{CO}_{2}$ well mixed in the room with doors closed. $\mathrm{CO}_{2}$ level was then measured at one-minute interval using the $\mathrm{CO}_{2}$ sensor as described above. The length of the $\mathrm{CO}_{2}$ measurement period is dependent on the ventilation rates of the room. For rooms with excellent ventilation, $\mathrm{CO}_{2}$ level decays rapidly and a measurement period of 30 minutes may be adequate. For rooms with very poor ventilation, $\mathrm{CO}_{2}$ measurements may need to continue for several hours or overnight to allow a sufficient level of $\mathrm{CO}_{2}$ clearance for calculating the ventilation rate using the baking soda and vinegar method $\left(\mathrm{ACH}_{\mathrm{BV}}\right)$ based on equation \#2 described above.

Estimating ventilation rate by time to $63 \%$ removal of excess $\mathrm{CO}_{2}$ : Based on the commonly used formula for the rate of purging airborne contaminants, one complete air change will replace $63 \%$ of the airborne contaminants in the room with outdoor air [22-24]. Ventilation rate can therefore be simply calculated using the time needed to reach $63 \%$ reduction of excess $\mathrm{CO}_{2}$ from its peak level:

$$
\mathrm{ACH}_{\mathrm{T} 63 \%}=60 /\left(\mathrm{t}_{2}-\mathrm{t}_{1}\right) \text {, with } \mathrm{t}_{1}=0 \text {. }
$$

where $t_{1}=$ initial timepoint in minutes with indoor $\mathrm{CO}_{2}$ at peak level, and $t_{2}=$ timepoint in minutes when excess $\mathrm{CO}_{2}$ is reduced by $63 \%$. Indoor $\mathrm{CO}_{2}$ at peak level $\left(\mathrm{C}_{\mathrm{S}}\right)$ is the sum of outdoor $\mathrm{CO}_{2}$ $\left(C_{R}\right)$ and excess $\mathrm{CO}_{2}\left(C_{E}\right)$ generated by dry ice or baking soda. As $\mathrm{CO}_{2}$ measurement starts at peak level in this experiment, $t_{1}$ is therefore always 0 . Time needed to remove $63 \% C_{E}$, or $t_{2}$, is the timepoint when indoor $\mathrm{CO}_{2}$ level is at $\mathrm{C}_{63 \% E}=\mathrm{C}_{S}-63 \% \mathrm{C}_{E}$, where $\mathrm{C}_{E}=\mathrm{C}_{S}-\mathrm{C}_{R}$.

Statistical analysis: To understand factors associated with $\mathrm{CO}_{2}$ levels in dental treatment rooms, we performed multiple regression analysis using $\mathrm{CO}_{2}$ levels as dependent variable and number of persons in the room, ventilation rate, room sizem and outdoor $\mathrm{CO}_{2}$ level as independent variables. We analyzed the dynamics of $\mathrm{CO}_{2}$ levels during dental treatment procedures using descriptive analysis and compared the differences in steady state $\mathrm{CO}_{2}$ levels between rooms 
medRxiv preprint doi: https://doi.org/10.1101/2021.02.04.21251153; this version posted February 8, 2021. The copyright holder for this preprint (which was not certified by peer review) is the author/funder, who has granted medRxiv a license to display the preprint in perpetuity.

All rights reserved. No reuse allowed without permission.

with poor and good ventilations using t-tests. $\mathrm{ACH}_{\text {VENT }}$ was compared with $\mathrm{ACH}$ calculated with different methods based on $\mathrm{CO}_{2}$ levels to assess the correlation (Pearson's $\mathrm{r}$ ) between the two methods of ventilation rate assessments. As the primary goal of the present study was to determine the validity of pragmatic methodologies that could be used by dental practitioners who do not have access to sophisticated instruments to assess the ventilation rate of their clinic spaces, we focused the analysis on $\mathrm{CO}_{2}$ generation using baking soda and vinegar and ventilation rate calculation using time needed to achieve $63 \%$ reduction of peak $\mathrm{CO}_{2}$ levels $\left(\mathrm{ACH}_{\mathrm{BV} 63 \%}\right)$.

\section{Results:}

Mechanical ventilation rate of the dental treatment rooms: The volumetric sizes, airflow rates and mechanical ventilation rates of dental treatment rooms are presented in Table 1 . The 10 operatories are on average $882 \mathrm{ft}^{3}$ in volume (range 667 to $1221 \mathrm{ft}^{3}$ ). ACHVENT varied from 3.9 to 35.0 with a mean of $13.2( \pm 10.6)$. A majority $(7 / 10)$ of the treatment rooms have greater supply than exhaust air flow rates with positive differentials between $\mathrm{ACH}_{\mathrm{S}}$ and $\mathrm{ACH}_{\mathrm{E}}$ at two or greater; and one room have significantly greater exhaust than supply airflow rates with a highly negative differential between $\mathrm{ACH}_{\mathrm{s}}$ and $\mathrm{ACH}_{\mathrm{E}}$. A majority of the treatment rooms (7/10) have $\mathrm{ACH}$ VENT at or greater than 6 , and 4 of the 10 rooms had $A C H_{V E N T}$ greater than 10.

$\mathrm{CO}_{2}$ levels during dental treatment procedures: As shown in Figure 1, $\mathrm{CO}_{2}$ levels were significantly higher in the room with low ventilation rate $(\mathrm{ACH}=3.9)$ and reached a peak of nearly 1600 ppm when 6 persons were in the room. The increased number of persons were related to teaching activities involving dental implant surgery where additional graduate students were allowed to observe the procedures. Comparing the two rooms with the same number of persons in the room for the same restorative procedures, $\mathrm{CO}_{2}$ levels reached $1100 \mathrm{ppm}$ at the peak in the room with $3.9 \mathrm{ACH}$ but stayed below 700 ppm in the room with $35 \mathrm{ACH}(\mathrm{p}<0.0001)$. $\mathrm{CO}_{2}$ accumulation appeared to be associated with crowding and low ventilation rate.

Continuous $\mathrm{CO}_{2}$ monitoring in dental treatment rooms: We continuously monitored the $\mathrm{CO}_{2}$ levels for 24 hours in 10 treatment rooms with various ventilation rates in different departments. The working hours were from 8:00am to $5: 00 \mathrm{pm}$ with lunch breaks from 12:30pm to 1:30pm for some and 1:00pm to 2:00pm for other departments. The dental procedures included prophylaxis, extractions, restoratives, endodontics, dental implant surgery, periodontal surgery and exams. Number of persons in the rooms varied from 2 to 6 , with more people in the room during dental implant surgeries. The $\mathrm{CO}_{2}$ levels in early morning (5:00 - 7:00am) were at an level of $421 \pm 10 \mathrm{ppm}$, similar to the outdoor levels (413 $\pm 15 \mathrm{ppm})$ (Table 2, Figure 2). The steady 
medRxiv preprint doi: https://doi.org/10.1101/2021.02.04.21251153; this version posted February 8, 2021. The copyright holder for this preprint (which was not certified by peer review) is the author/funder, who has granted medRxiv a license to display the preprint in perpetuity.

All rights reserved. No reuse allowed without permission.

state $\mathrm{CO}_{2}$ level $\left(\mathrm{C}_{\mathrm{SS}}\right)$ during dental procedures, which was the mean concentrations of $\mathrm{CO}_{2}$ at the plateau level when the number of persons in the room stays unchanged for at least $5 \mathrm{~min}$, ranged from $543 \mathrm{ppm}$ to $1,374 \mathrm{ppm}(786 \pm 207 \mathrm{ppm})$ in the 10 dental treatment rooms. Multiple regression analysis showed that steady state $\mathrm{CO}_{2}$ levels in dental treatment rooms were statistically significantly correlated to number of persons in the room $(\beta=90.2, p=0.006)$, mechanical ventilation rate $(\beta=11.0, p=0.001)$ and the volumetric size of the room $(\beta=-0.50$, $\mathrm{p}=0.049)$, but not to outside air $\mathrm{CO}_{2}$ levels $(\beta=4.15, \mathrm{p}=0.160)$. These findings confirmed that more people in smaller room with low ventilation rate facilitate $\mathrm{CO}_{2}$ accumulation in dental treatment rooms.

As shown in Figure 2, $\mathrm{CO}_{2}$ levels in rooms with $\mathrm{ACH}$ higher than 6 rarely reach 800 ppm. In rooms with $\mathrm{ACH}$ lower than 6 , however, the $\mathrm{CO}_{2}$ levels were consistently greater than $800 \mathrm{ppm}$ and approached 1,400 ppm in a room with $\mathrm{ACH} 3.9$ when number of persons in the room was as high as 6 during clinical teaching activities related to dental implant procedures.

Ventilation rates by steady state $\mathrm{CO}_{2}$ level modeling in dental treatment rooms: Based on steady state $\mathrm{CO}_{2}$ level $\left(\mathrm{C}_{\mathrm{SS}}\right)$ and outdoor $\mathrm{CO}_{2}$ level $\left(\mathrm{C}_{\mathrm{R}}\right)$ presented in Table 2, ventilation rates with $\mathrm{CO}_{2}$ generation at $0.30 \mathrm{~L} / \mathrm{min}\left(\mathrm{ACH}_{\mathrm{Ss} 30}\right)$ and $0.46 \mathrm{~L} / \mathrm{Min}\left(\mathrm{ACH}_{\mathrm{SS} 46}\right)$ in the clinical space were calculated using equation \#1 for two dental treatment procedures in each room. As expected, $\mathrm{ACH}_{\mathrm{ss} 30}$ values (Mean 8.3, SD 3.7) were significantly lower than $\mathrm{ACH}_{\mathrm{sS} 46}$ (Mean 12.6, SD 5.7) (mean difference $=-4.5$, paired $\mathrm{t}=-6.97, \mathrm{p}<0.0001$ ). Both $\mathrm{ACH}_{\mathrm{SS} 30}$ and $\mathrm{ACH}_{\mathrm{SS} 46}$ were similarly well correlated with $\mathrm{ACH}_{\text {VENT }}(\mathrm{r}=0.83, \mathrm{p}=0.003) . \mathrm{ACH}_{\mathrm{SS} 30}$ approximated closely to the mechanical ventilation rates in rooms with $\mathrm{ACH}_{\mathrm{VENT}} \leq 6$ (mean difference=-0.6, paired $\mathrm{t}=-1.24$, $p=0.304$ ), but significantly underestimated those in rooms with $A C H_{V E N T}>6$ (mean difference=8.7, paired $t=-2.59, p=0.049$ ). The opposite is true for $\mathrm{ACH}_{s s 46}$, it significantly overestimated the ventilation rates in rooms with $A C H_{V E N T} \leq 6$ (mean difference=3.7, paired $t=6.78, p=0.007$ ), but approximated closer to those in rooms with $\mathrm{ACH}_{\mathrm{VENT}}>6$ (mean difference=-3.5, paired $\mathrm{t}=-1.14$, $p=0.307$ ) (Table 3).

As ventilation rate is likely below $6 \mathrm{ACH}$ in most dental treatment rooms in private dental practices in small free-standing buildings in the US[13], $\mathrm{CO}_{2}$ generation rate (GP) of $0.30 \mathrm{~L} / \mathrm{min}$ is more appropriate for ventilation rate estimate using equation \#1. We listed the corresponding steady state $\mathrm{CO}_{2}$ levels and ventilation rates in rooms with various sizes with 8-ft ceiling height using $n=3, G_{P}=0.30 \mathrm{~L} / \mathrm{min}$, and $C_{R}=400 \mathrm{ppm}$ (Supplemental Table 1). DCPs may use the steady state $\mathrm{CO}_{2}$ levels measured in their dental treatment rooms to roughly estimate the ventilation rate using this table. 
medRxiv preprint doi: https://doi.org/10.1101/2021.02.04.21251153; this version posted February 8, 2021. The copyright holder for this preprint (which was not certified by peer review) is the author/funder, who has granted medRxiv a license to display the preprint in perpetuity.

All rights reserved. No reuse allowed without permission.

Ventilation rates by $\mathrm{CO}_{2}$ decays using dry ice or baking soda: Results of ventilation estimates by $\mathrm{CO}_{2}$ decay using dry ice or baking soda and vinegar are shown in Table 3. Both methods appeared to be reliable in assessing the ventilation rates of dental treatment rooms. The $\mathrm{CO}_{2}$ decay curves demonstrate that $\mathrm{CO}_{2}$ levels decreased faster over time in rooms with high $\mathrm{ACH}_{\text {VENT }}$ (Figure $3 \mathrm{~A}, \mathrm{~B}$ ). $\mathrm{ACH}_{\mathrm{DI}}$ values ranged from 3.6 to $28.5(11.2 \pm 8.4$ ) and were highly correlated with the mechanical ventilation rates $\mathrm{ACH}_{\mathrm{VENT}}(\mathrm{r}=0.99, \mathrm{p}<0.0001)$ (Figure $\left.3 \mathrm{C}\right)$. ACH was lower than $A C H_{V E N T}$ (mean difference $=2.0$, paired $t=2.32, p=0.046$ ). Similarly, $A C H_{B V}$ ranged from 4.7 to $27.0(11.8 \pm 8.1)$ and also correlated highly with $A_{C H} H_{V N T}(r=0.98, p<0.0001)$ (Figure $3 \mathrm{D}$ ). There was no statistically significant difference between $\mathrm{ACH}_{\mathrm{BV}}$ and $\mathrm{ACH} \mathrm{H}_{\mathrm{VENT}}$ (mean difference $=1.4$, paired $t=1.48, p=0.174$ ), or between $A_{C H}$ and $A C H_{D I}$ (mean difference $=0.59$, paired $t=1.26, p=0.239)$.

Ventilation rates by time to $63 \%$ removal of excess $\mathrm{CO}_{2}$ generated by dry ice or baking soda: Ventilation rates calculated by time needed to remove $63 \%$ of excess $\mathrm{CO}_{2}$ generated by dry ice of baking soda are presented in Table 3. $\mathrm{ACH}_{\mathrm{DI} 63}$ values ranged from 4.1 to $30.8(11.5 \pm 8.6)$ and were highly correlated with the mechanical ventilation rates $\mathrm{ACH}_{\mathrm{VENT}}(\mathrm{r}=0.98, p<0.0001)$ (Figure $4 \mathrm{~A}$ ). There was no statistically significant difference between $\mathrm{ACH}_{\mathrm{DI} 63}$ and $\mathrm{ACH}$ VENT (mean difference $=1.8$, paired $t=1.93, p=0.086$ ).

Similarly, $\mathrm{ACH}_{\mathrm{BV} 63}$ ranged from 4.6 to $27.3(11.9 \pm 8.1)$ and correlated highly with $\mathrm{ACH}_{\mathrm{VENT}}$ $(r=0.98, p<0.0001)$ (Figure 4 B). There was no statistically significant difference between $\mathrm{ACH}_{\mathrm{BV} 63}$ and $\mathrm{ACH}_{\mathrm{VENT}}$ (mean difference = 1.3, paired $\mathrm{t}=1.34, \mathrm{p}=0.213$ ), or between $\mathrm{ACH}_{\mathrm{BV} 63}$ and $\mathrm{ACH}_{\mathrm{DI63}}$ (mean difference $=0.50$, paired $\mathrm{t}=0.76, \mathrm{p}=0.467$ ).

A Microsoft Excel template is provided in Supplemental Table 2 that will allow DCPs to calculate the ventilation rate of their offices by inputting the values of peak $\mathrm{CO}_{2}$ level $\left(\mathrm{C}_{\mathrm{s}}\right)$, outdoor $\mathrm{CO}_{2}$ level $\left(C_{R}\right)$ and time $(\mathrm{min})$ needed to reach $63 \%$ removal of excess $\mathrm{CO}_{2}$ generated by dry ice or baking soda.

\section{Discussion:}

The findings of the present study indicate that dental operatories with low mechanical ventilation rates and overcrowding facilitate $\mathrm{CO}_{2}$ accumulations. Ventilation rates could be measured by assessing natural or experimental build-up of $\mathrm{CO}_{2}$ levels in dental treatment rooms using a consumer-grade $\mathrm{CO}_{2}$ sensor. We found that ventilation rates in $\mathrm{ACH}$ could be accurately assessed by observing the changes in $\mathrm{CO}_{2}$ levels after a simple mixing of household baking soda and vinegar in dental settings. Time needed to remove $63 \%$ of excess $\mathrm{CO}_{2}$ generated by 
medRxiv preprint doi: https://doi.org/10.1101/2021.02.04.21251153; this version posted February 8, 2021. The copyright holder for this preprint (which was not certified by peer review) is the author/funder, who has granted medRxiv a license to display the preprint in perpetuity.

All rights reserved. No reuse allowed without permission.

baking soda could be used to accurately calculate the ventilation rates with the help of a basic calculator.

Our findings show that $\mathrm{CO}_{2}$ level may consistently stay above $800 \mathrm{ppm}$ in rooms with ventilation rates below $6 \mathrm{ACH}$, especially when three or more persons (including the patient who was not wearing a mask) are in the room during dental treatments. We observed that $\mathrm{CO}_{2}$ level stayed above 1000 ppm and approached 1600 ppm when 3 to 6 persons were in a room with $3.9 \mathrm{ACH}$ in clinical teaching scenarios involving dental implant treatment. High levels of $\mathrm{CO}_{2}$ indicate high concentrations of respiratory aerosols in the room. It is possible that these aerosols contain pathogens if the patient is not wearing a mask and is infected but asymptomatic or presymptomatic. Effective mitigation measures will be required in these rooms to improve the air quality even without the ongoing infectious disease pandemic. Overcrowding should be avoided in rooms with poor ventilation. In dental operatories with ventilation rates higher than $10 \mathrm{ACH}$, the $\mathrm{CO}_{2}$ levels stayed consistently below 700 ppm in most cases with 3 persons in the room. Our data demonstrated a clear dependency of $\mathrm{CO}_{2}$ levels on number of persons in the room and the mechanical ventilation rate. $\mathrm{CO}_{2}$ level is a proxy for indoor air quality as it represents the fraction of rebreathed air, or the proportion of inhaled air that was exhaled by others in the same indoor environment. Though numerous epidemiological studies indicate $\mathrm{CO}_{2}$ begins to have negative health effects at $700 \mathrm{ppm}$ and respiratory symptoms may occur when indoor $\mathrm{CO}_{2}$ concentration is above 1000 ppm [25], our main concern is the concurrent accumulation of respiratory aerosols that may contain infectious disease pathogens. Numerous studies have shown that exhaled air from infected patients contains respiratory disease pathogens, including rhinovirus, influenza virus and Mycobacterium tuberculosis [4, 26-28]. Patients with early stages of COVID-19 may release millions of SARS CoV-2 viral copies per hour in exhaled air [29]. In a recent study that modeled factors associated with the spread of respiratory infectious disease in dental offices, $\mathrm{CO}_{2}$ levels were found to play the most important role on the risk of infectious disease transmission [11]. $\mathrm{CO}_{2}$ levels at $774 \mathrm{ppm}$ was considered as low risk but those at or above 1135 ppm may increase the risk of disease transmission in dental offices [11].

It is important to point out that the setting for the current study is a postdoctoral dental training institution affiliated with an academic medical center, which may differ significantly in ventilation conditions from private dental practices that have a solo or a few dental practitioners. Ventilation conditions in different dental settings are largely unknown as the ventilation design of dental offices is not regulated as other outpatient healthcare facilities that are required to have 6 to 15 $\mathrm{ACH}$ by ASHRAE and CDC [30,31]. Godwin and colleagues reported that ventilation rate was 
medRxiv preprint doi: https://doi.org/10.1101/2021.02.04.21251153; this version posted February 8, 2021. The copyright holder for this preprint (which was not certified by peer review) is the author/funder, who has granted medRxiv a license to display the preprint in perpetuity.

All rights reserved. No reuse allowed without permission.

1.12 ACH in dental operatories of a small dental clinic $\left(2400 \mathrm{ft}^{2}\right)$ [13], which is significantly lower than the mean of $13 \mathrm{ACH}$ in the present study but resembles more closely to the mean of 1.09 $\mathrm{ACH}$ in typical residential households in the US [32].

Accurate and reliable measurements of ventilation rate in various dental settings are important for risk assessment and for risk mitigation planning in an era of frequent infectious disease pandemics. Mechanical ventilation rate is assessed by quantifying the amount of outdoor air flowing into and out of an indoor space using highly sophisticated instruments operated by trained professionals [16]. Technical barriers may have contributed to the scarcity of information regarding ventilation in dental settings. Besides direct air flow measurements, ventilation rate could be estimated using $\mathrm{CO}_{2}$ as a tracer gas. $\mathrm{CO}_{2}$ in an indoor space could be built up to a significantly higher level than in outdoor air, either through natural generation by the occupants or through experimental release of the gas in the indoor spaces [5, 33, 34]. Analysis of the steady state $\mathrm{CO}_{2}$ levels or the rate of $\mathrm{CO}_{2}$ concentration decays, which is directly dependent on the outdoor air flow rate from the ventilation system, will allow an estimate of the ventilation rate of the indoor space. We found that modeling the steady state $\mathrm{CO}_{2}$ levels using equation \#1 correlated reasonably well with the mechanical ventilation rate, but may either under- or overestimate the ventilation rate based on different assumptions of human $\mathrm{CO}_{2}$ generation rates. In comparison, the $\mathrm{CO}_{2}$ concentration decay method relied on actual $\mathrm{CO}_{2}$ levels measured at the beginning and the end of a decay period (equation \#2) and provided more accurate assessments and better approximation to the mechanical ventilation rates. $\mathrm{CO}_{2}$ concentrations in dental operatories could be built up to a level of about 1500 to 2500 ppm in 2 minutes using either dry ice or baking soda and vinegar. $\mathrm{CO}_{2}$ decays could then be monitored using a $\mathrm{CO}_{2}$ sensor that logs data in one-minute intervals. There are many affordable consumer-grade $\mathrm{CO}_{2}$ sensors readily available and suitable for the purpose of observing $\mathrm{CO}_{2}$ level changes over a period of time, from several minutes to several hours depending on the mechanical ventilation rates. The $\mathrm{CO}_{2}$ sensor used in the present study was purchased online for $\$ 159$ and appeared to be a reliable tool for monitoring indoor $\mathrm{CO}_{2}$ levels in dental settings. Although ventilation rate in $\mathrm{ACH}$ could be calculated by fitting a linear regression line over time into the natural log scale of time-varying concentrations of $\mathrm{CO}_{2}$ levels (equation \#2), we found that a simplified method (equation \#4) provided equally if not more accurate estimate of ventilation rate. As it is known that one complete air change will replace $63 \%$ of the airborne contaminants in the room with outdoor air [22-24], ventilation rate could be easily calculated using the time needed to remove $63 \%$ of excess $\mathrm{CO}_{2}$ as a contaminant. For example, assuming 
medRxiv preprint doi: https://doi.org/10.1101/2021.02.04.21251153; this version posted February 8, 2021. The copyright holder for this preprint (which was not certified by peer review) is the author/funder, who has granted medRxiv a license to display the preprint in perpetuity.

All rights reserved. No reuse allowed without permission.

$\mathrm{CO}_{2}$ level in outdoor air is $400 \mathrm{ppm}$, and peak $\mathrm{CO}_{2}$ level is $1500 \mathrm{ppm}$ after placing dry ice or baking soda inside the dental office for 2 minutes, excess $\mathrm{CO}_{2}$ inside the dental office will be $1500-400=1100$ ppm at peak. The $\mathrm{CO}_{2}$ level that represents $63 \%$ removal of excess $\mathrm{CO}_{2}$ is therefore $1500-63 \% \times 1100=807$ ppm. If it takes 15 min for the $\mathrm{CO}_{2}$ level to reach $807 \mathrm{ppm}$ from the peak of 1500 ppm, ventilation rate in $\mathrm{ACH}$ will be 60/15 = 4; and if it takes 2 hours for the $\mathrm{CO}_{2}$ level to reach $807 \mathrm{ppm}, \mathrm{ACH}$ will be $60 / 120=0.5$. This method will allow dental practitioners to accurately estimate the ventilation rate in $\mathrm{ACH}$ using a simple calculator.

Ventilation rates measured by the $\mathrm{CO}_{2}$ decay methods were approximately $15 \%$ lower on average than those measured by air flow sensors at the air supply inlets or exhaust returns of the ventilation system. This discrepancy is expected as indoor $\mathrm{CO}_{2}$ could only be removed by fresh outdoor air brought in by the ventilation system or by outdoor air infiltrated through leaky doors and windows [35]. As the mechanically ventilated air was not composed of $100 \%$, but $60 \%$ outdoor air at the time of this study, the $\mathrm{CO}_{2}$ removal rate was understandably lower than the total air flow rate. In practical sense, ventilation rates measured by $\mathrm{CO}_{2}$ decay methods are better indicators of outdoor air flow, which is more important than the recycled indoor air flow measured by airflow sensors in terms of air contaminant removal efficiencies.

Our data showed that household baking soda $\left(\mathrm{NaHCO}_{3}\right)$ and vinegar ( $5 \%$ acetic acid) could be used to generate $\mathrm{CO}_{2}$ in dental office to assess the ventilation rate by observing the $\mathrm{CO}_{2}$ concentration decays using a $\mathrm{CO}_{2}$ sensor and a basic calculator. This method will allow dental practitioners to reliably estimate the ventilation rate in their dental offices without expensive equipment and advanced technical skills. The test could be completed within 30 minutes in spaces with ventilation rate higher than $2 \mathrm{ACH}$ but may take longer time if the ventilation is significantly below $1 \mathrm{ACH}$. We recommend to plan a two-hour observation time during off-hours with the building ventilation system operating in its normal setting.

We consider that it is very important for every dental practitioner to be able to accurately assess the ventilation rate in their working environments. Epidemiological data showed that transmission of COVID-19 is almost exclusively an indoor phenomenon, with $99.97 \%$ of the transmissions occurring in an indoor environment [29]. Airborne transmission through respiratory aerosols is increasingly recognized as a major driver for the COVID-19 pandemic [36-38]. As essential healthcare providers, dental professionals work in the frontline during the pandemic and need to adopt measures to mitigate the risk of aerosol transmission in addition to droplet and contact precautions that have been the standard of infection control in dental offices [39]. 
medRxiv preprint doi: https://doi.org/10.1101/2021.02.04.21251153; this version posted February 8, 2021. The copyright holder for this preprint (which was not certified by peer review) is the author/funder, who has granted medRxiv a license to display the preprint in perpetuity.

All rights reserved. No reuse allowed without permission.

We recommend that mitigation measures be taken for dental treatment rooms that have a ventilation rate below $15 \mathrm{ACH}$, which is required for procedure rooms in outpatient healthcare facilities by CDC guidelines [30]. While in theory the most effective measure for air quality improvement in dental offices is to increase outdoor air flow rate through the mechanical ventilation system or through natural ventilation by opening doors and windows, such measure is severely limited by the weather or climate conditions and often impractical or impossible to realize in practice. An effective alternative is to improve air filtration using upgraded filters in the ventilation system and portable air cleaners (PAC) equipped with high efficiency particulate air (HEPA) filters. We showed that a PAC with a HEPA filter and a clean air delivery rate of 250 cubic feet per minute could add an equivalent of $17 \mathrm{ACH}$ to an average sized dental operatory (10 ft L, 11ft W, $8 \mathrm{ft} \mathrm{H}$ ) [17]. The PAC was especially effective in removing aerosols from rooms with low mechanical ventilation rate because of the lack of disturbance from the high air flow of the ventilation system [17]. For larger spaces where PAC is not practical or effective, upper room ultraviolet germicidal irradiation (UVGI) system may be considered as it has been shown to be effective in healthcare settings [40-42]. The upper room UVGI system requires professional installation and maintenance to ensure its safe operation.

In summary, we found that dental operatories with low ventilation rates $\left(\mathrm{ACH}_{\mathrm{VENT}} \leq 6\right)$ facilitate $\mathrm{CO}_{2}$ accumulations. Crowding inside the room contributed to elevated $\mathrm{CO}_{2}$ levels. Ventilation rates could be reliably calculated by observing the changes in $\mathrm{CO}_{2}$ levels after a simple mixing of household baking soda and vinegar in dental settings. Time needed to remove $63 \%$ of excess $\mathrm{CO}_{2}$ generated by baking soda could be used to accurately assess the ventilation rates using a consumer-grade $\mathrm{CO}_{2}$ sensor and a basic calculator. For rooms with ventilation rate below $15 \mathrm{ACH}$, we suggest the addition of a PAC with HEPA filter and proper clean air delivery rate to facilitate air quality improvement in dental treatment rooms.

\section{Acknowledgement:}

The authors declare no conflict of interests. This study is supported in part by the Eastman Institute for Oral Health Foundation, Rochester, New York. We thank building engineers Dan Mateer and Kevin McLellan at Johnson Control Inc. and mechanical engineers Ray Richard and Karen Pembroke at Facility Operations, University of Rochester Medical Center for their technical expertise and assistance with the present study.

\section{Figures:}


medRxiv preprint doi: https://doi.org/10.1101/2021.02.04.21251153; this version posted February 8, 2021. The copyright holder for this preprint (which was not certified by peer review) is the author/funder, who has granted medRxiv a license to display the preprint in perpetuity. All rights reserved. No reuse allowed without permission.
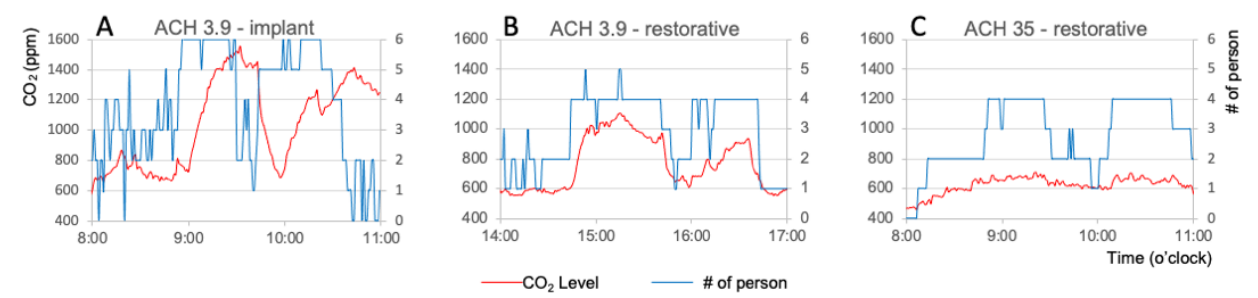

Figure 1: $\mathrm{CO}_{2}$ levels during dental treatment procedures in operatories with low and high mechanical ventilation. A: Significant $\mathrm{CO}_{2}$ accumulation occurred in a room with low ventilation $(\mathrm{ACH}$ $=3.9$ ) and multiple persons in the room during clinical teaching activities for dental implant surgery. $\mathrm{E}, \mathrm{F}: \mathrm{CO}_{2}$ level is associated with ventilation rate in rooms with the same number of persons. Peak $\mathrm{CO}_{2}$ level reached $1100 \mathrm{ppm}$ in the room with $3.9 \mathrm{ACH}(\mathrm{B})$ but stayed under $700 \mathrm{ppm}$ in the rooms with $35 \mathrm{ACH}(\mathrm{C})$. 
medRxiv preprint doi: https://doi.org/10.1101/2021.02.04.21251153; this version posted February 8, 2021. The copyright holder for this preprint

(which was not certified by peer review) is the author/funder, who has granted medRxiv a license to display the preprint in perpetuity.

All rights reserved. No reuse allowed without permission.
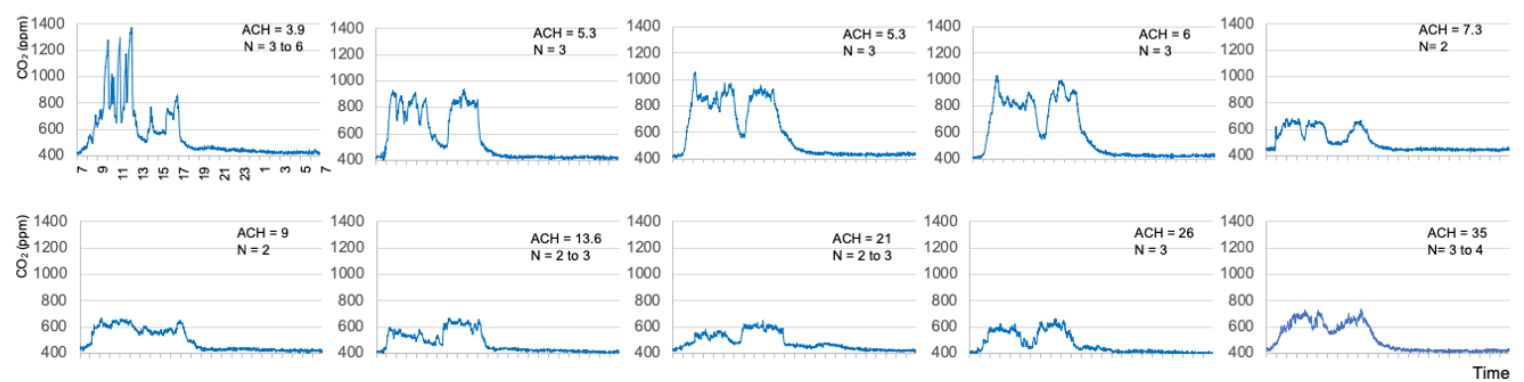

Figure 2: 24-hour continuous measurements of $\mathrm{CO}_{2}$ levels in 10 dental treatment rooms with various ventilation rates. $\mathrm{CO}_{2}$ accumulation occurred in rooms with lower ventilation rates $(\mathrm{ACH} \leq 6)$. $\mathrm{CO} 2$ levels stayed under $800 \mathrm{ppm}$ in rooms with higher ventilation rate and lower number of persons. $\mathrm{CO}_{2}$ level in nonworking hours is close to that of outdoor at $400 \mathrm{ppm}$ in all the rooms. 

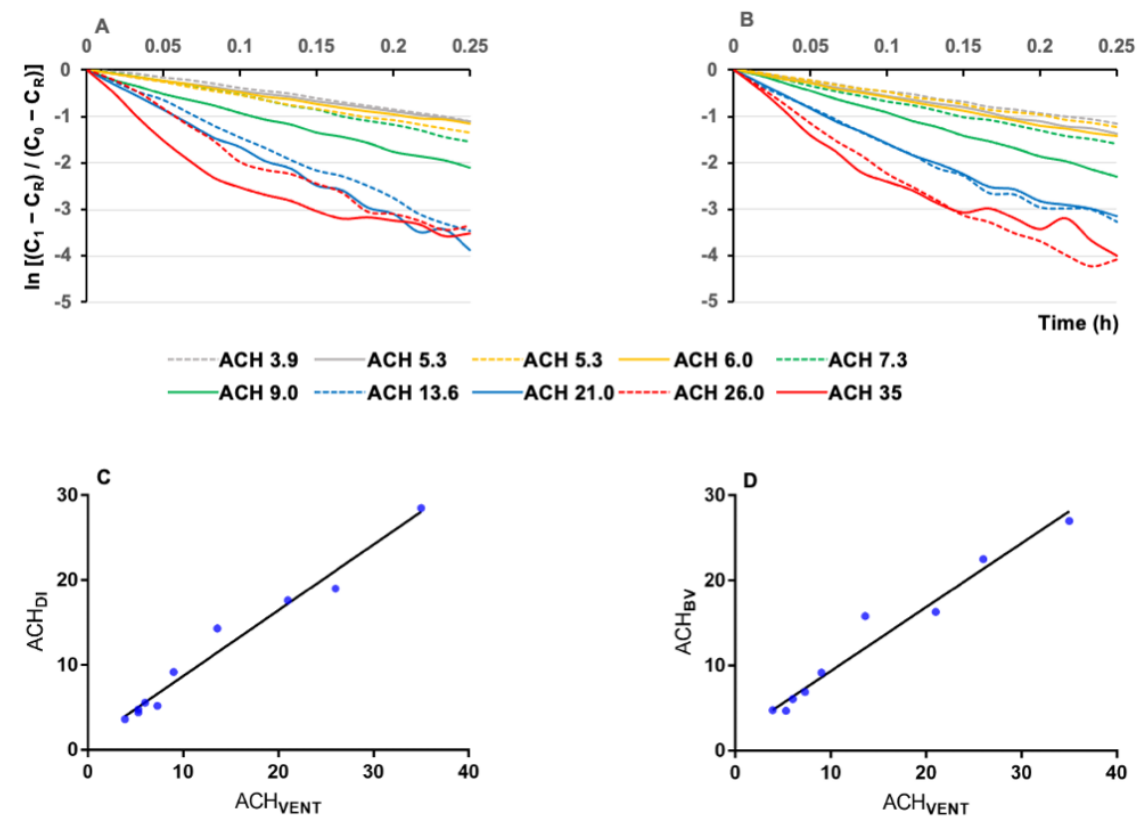

Figure 3. $\mathrm{A}: \mathrm{CO}_{2}$ decay constants by dry ice, $\mathrm{B}: \mathrm{CO}_{2}$ decay constants by baking soda and vinegar; $\mathrm{C}$ and D: association between mechanical ventilation rates measure by air flow (ACHVENT) and ventilation rates measured by $\mathrm{CO}_{2}$ decay using dry ice $\left(\mathrm{ACH}_{\mathrm{DI}}\right)$ and baking soda and vinegar $\left(\mathrm{ACH} \mathrm{BV}_{\mathrm{B}}\right)$ in dental treatment rooms. Rooms with high mechanical ventilation rates showed rapid decrease of $\mathrm{CO}_{2}$ concentrations over time (A, B). Both $\mathrm{ACH}_{\mathrm{DI}}$ and $\mathrm{ACH}_{\mathrm{BV}}$ are linearly correlated with $\mathrm{ACH}_{\text {Vent }}(\mathrm{C}, \mathrm{D})$. 
A

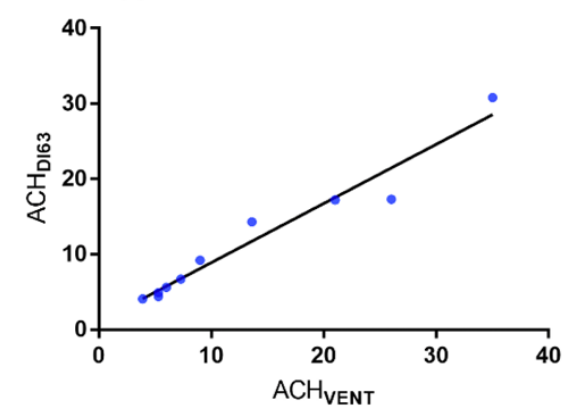

B

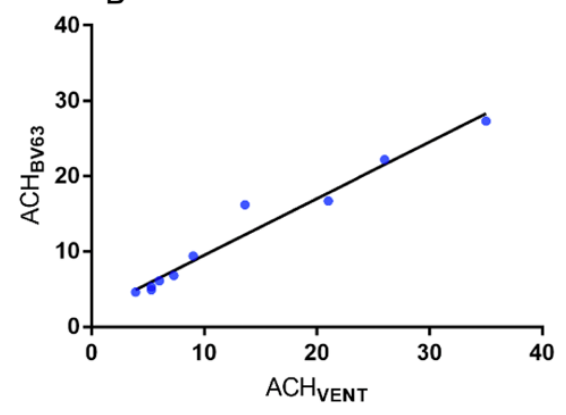

Figure 4. $A$ : Correlations between ventilation rate by air flow $\left(A C H_{V E N T}\right)$ and ventilation rates by time needed to reach $63 \%$ of excess $\mathrm{CO}_{2}$ generated using $\mathrm{A}$ : dry ice $\left(\mathrm{ACH}_{\mathrm{DI} 63}\right)$ and $\mathrm{B}$ : baking soda and vinegar $\left(\mathrm{ACH}_{\mathrm{B} 63}\right)$. 
medRxiv preprint doi: https://doi.org/10.1101/2021.02.04.21251153; this version posted February 8, 2021. The copyright holder for this preprint (which was not certified by peer review) is the author/funder, who has granted medRxiv a license to display the preprint in perpetuity.

All rights reserved. No reuse allowed without permission.

Tables:

Table 1: Volumetric sizes and mechanical ventilation rates of dental operatories

\begin{tabular}{lcrrrrrr}
\hline $\mathbf{R m} \#$ & $\begin{array}{c}\text { Volume } \\
\mathbf{f t}^{\mathbf{3}}\end{array}$ & $\begin{array}{c}\mathbf{S A F} \\
\mathbf{f t}^{3} \mathbf{m} \mathbf{m}\end{array}$ & $\begin{array}{c}\mathbf{E A F} \\
\mathbf{f t}^{3} / \mathbf{m i n}\end{array}$ & $\mathbf{A C H}_{\mathbf{S}}$ & $\mathbf{A C H}_{\mathbf{E}}$ & $\mathbf{A C H}_{\text {VENT }}$ & Floor \\
\hline 002 & 815 & 82 & 27 & 6.0 & 2.0 & 6.0 & 0 \\
\hline 003 & 787 & 69 & 27 & 5.3 & 2.1 & 5.3 & 0 \\
\hline 008 & 1221 & 149 & 103 & 7.3 & 5.1 & 7.3 & 2 \\
\hline 012 & 1015 & 152 & 64 & 9.0 & 3.8 & 9.0 & 2 \\
\hline 019 & 686 & 59 & 400 & 5.2 & 35.0 & 35.0 & 1 \\
\hline 021 & 861 & 75 & 51 & 5.3 & 3.6 & 5.3 & 1 \\
\hline 022 & 833 & 55 & 46 & 3.9 & 3.3 & 3.9 & 1 \\
\hline 031 & 962 & 337 & 210 & 21.0 & 13.1 & 21.0 & 2 \\
\hline 033 & 667 & 289 & 220 & 26.0 & 19.8 & 26.0 & 2 \\
\hline Mean & 970 & 211 & 220 & 13.1 & 13.6 & 13.6 & 2 \\
\hline SD & 882 & 148 & 137 & 10.2 & 10.1 & 13.2 & - \\
\hline SAF: & 166 & 101 & 122 & 7.6 & 10.6 & 10.6 & - \\
\hline
\end{tabular}

SAF: supply airflow rate in cubic feet per minute. EAF: exhaust airflow rate in cubic feet per minute. $\mathrm{ACH}_{\mathrm{s}}$ : air change per hour based on supply airflow rate. $\mathrm{ACH}_{\mathrm{E}}$ :air change per hour based on exhaust airflow rate. ACHVENT: air change per hour based on mechanical ventilation. OA\%: outside air percentage drawn by the air handlers. 
medRxiv preprint doi: https://doi.org/10.1101/2021.02.04.21251153; this version posted February 8, 2021. The copyright holder for this preprint (which was not certified by peer review) is the author/funder, who has granted medRxiv a license to display the preprint in perpetuity.

All rights reserved. No reuse allowed without permission.

Table 2: Steady state $\mathrm{CO}_{2}$ levels during treatment procedures and ventilation rate estimates based on low $(0.3 \mathrm{~L} / \mathrm{min})$ and high $(0.46 \mathrm{~L} / \mathrm{min})$ assumptions of human $\mathrm{CO}_{2}$ generation rates

\begin{tabular}{|c|c|c|c|c|c|c|}
\hline Rm \# & Procedure & $\begin{array}{c}\mathbf{n} \\
\text { persons }\end{array}$ & $\begin{array}{c}C_{\text {ss }} \\
\text { ppm }\end{array}$ & $\begin{array}{c}\mathrm{C}_{\mathrm{R}} \\
\mathrm{Ppm}\end{array}$ & $\mathrm{ACH}_{\mathrm{SS} 30}$ & $\mathrm{ACH}_{\mathrm{SS} 46}$ \\
\hline \multirow{2}{*}{002} & Exam & 4 & 1014 & 410 & 5.2 & 7.9 \\
\hline & Extraction & 4 & 978 & 410 & 5.5 & 8.4 \\
\hline \multirow{2}{*}{003} & Extraction & 4 & 960 & 410 & 5.9 & 9.0 \\
\hline & Extraction & 4 & 923 & 410 & 6.3 & 9.7 \\
\hline \multirow{2}{*}{008} & Hygiene & 2 & 673 & 435 & 4.4 & 6.7 \\
\hline & Hygiene & 2 & 629 & 435 & 5.4 & 8.2 \\
\hline \multirow{2}{*}{012} & Hygiene & 2 & 649 & 434 & 5.8 & 8.9 \\
\hline & Hygiene & 2 & 632 & 434 & 6.3 & 9.7 \\
\hline \multirow{2}{*}{019} & Extraction & 4 & 823 & 403 & 8.8 & 13.5 \\
\hline & Restorative & 3 & 616 & 403 & 13.1 & 20.1 \\
\hline \multirow{2}{*}{021} & Implant & 4 & 905 & 410 & 6.0 & 9.1 \\
\hline & Endo & 4 & 926 & 410 & 5.7 & 8.8 \\
\hline \multirow{2}{*}{022} & Implant & 6 & 1269 & 428 & 5.4 & 8.3 \\
\hline & Implant & 5 & 1089 & 428 & 5.8 & 8.8 \\
\hline \multirow{2}{*}{031} & Hygiene & 2 & 544 & 405 & 9.5 & 14.6 \\
\hline & Surgery & 4 & 611 & 405 & 12.9 & 19.7 \\
\hline \multirow{2}{*}{032} & Surgery & 3 & 584 & 404 & 15.8 & 24.2 \\
\hline & Exam & 4 & 633 & 404 & 16.7 & 25.5 \\
\hline \multirow{2}{*}{033} & Exam & 3 & 595 & 392 & 9.7 & 14.8 \\
\hline & Surgery & 4 & 662 & 392 & 10.6 & 16.2 \\
\hline Mean & - & 3.5 & 785.8 & 413.1 & 8.2 & 12.6 \\
\hline SD & - & 1.1 & 206.8 & 14.0 & 3.8 & 5.8 \\
\hline
\end{tabular}

Based on ventilation rate $\left.\mathrm{ACH}=6 \times 10^{4} \mathrm{n} \mathrm{GP}_{\mathrm{P}} / \mathrm{V}\left(\mathrm{Css}_{\mathrm{S}}-\mathrm{C}_{\mathrm{R}}\right)\right]$; Css: steady state $\mathrm{CO}_{2}$ level; $\mathrm{C}_{\mathrm{R}}$ : outdoor $\mathrm{CO}_{2}$ level; $\mathrm{ACH}$ ss30: ventilation estimate based on $\mathrm{CO}_{2}$ generation rate $\mathrm{G}_{\mathrm{p}}=0.3 \mathrm{~L} / \mathrm{min}$ per person; $\mathrm{ACH}_{\mathrm{ss} 30}$ : ventilation estimate based on $\mathrm{CO}_{2}$ generation rate $\mathrm{G}_{\mathrm{p}}=0.46 \mathrm{~L} / \mathrm{min}$ per person; 
medRxiv preprint doi: https://doi.org/10.1101/2021.02.04.21251153; this version posted February 8, 2021. The copyright holder for this preprint (which was not certified by peer review) is the author/funder, who has granted medRxiv a license to display the preprint in perpetuity.

All rights reserved. No reuse allowed without permission.

Table 3: Comparisons between mechanical ventilation rates and ventilation rates estimated from natural $\mathrm{CO}_{2}$ levels and $\mathrm{CO}_{2}$ released by dry ice and baking soda

\begin{tabular}{|c|c|c|c|c|c|c|c|}
\hline Rm \# & $\mathrm{ACH}_{\text {VENT }}$ & $\mathrm{ACH}_{\mathrm{SS} 30}$ & $\mathrm{ACH}_{\mathrm{SS} 46}$ & $\mathrm{ACH}_{\mathrm{DI}}$ & $\mathrm{ACH}_{\mathrm{BV}}$ & $\mathrm{ACH}_{\mathrm{DI63}}$ & $\mathrm{ACH}_{\mathrm{BV} 63}$ \\
\hline 002 & 6.0 & 5.4 & 8.2 & 5.6 & 6.1 & 5.6 & 6.1 \\
\hline 003 & 5.3 & 6.1 & 9.5 & 4.8 & 4.7 & 4.9 & 4.9 \\
\hline 008 & 7.3 & 4.9 & 7.5 & 5.2 & 6.9 & 6.7 & 6.8 \\
\hline 012 & 9.0 & 6.1 & 9.3 & 9.2 & 9.2 & 9.2 & 9.4 \\
\hline 019 & 35.0 & 11.0 & 16.8 & 28.5 & 27.0 & 30.8 & 27.3 \\
\hline 021 & 5.3 & 5.9 & 9.0 & 4.4 & 4.8 & 4.4 & 5.3 \\
\hline 022 & 3.9 & 5.6 & 8.6 & 3.6 & 4.8 & 4.1 & 4.6 \\
\hline 031 & 21.0 & 11.2 & 17.2 & 17.6 & 16.3 & 17.2 & 16.7 \\
\hline 031 & 26.0 & 16.3 & 24.9 & 19.0 & 22.5 & 17.3 & 22.2 \\
\hline 033 & 13.6 & 10.2 & 15.5 & 14.3 & 15.8 & 14.3 & 16.2 \\
\hline Mean & 13.2 & 12.6 & 8.3 & 11.2 & 11.8 & 11.5 & 11.9 \\
\hline SD & 10.6 & 5.7 & 3.7 & 8.4 & 8.1 & 8.2 & 8.1 \\
\hline
\end{tabular}

ACHVENT: mechanical ventilation rate; $\mathrm{ACH}_{\mathrm{sS} 30}$ : ventilation estimate by steady state $\mathrm{CO}_{2}$ level with $\mathrm{CO}_{2}$ generation at $0.3 \mathrm{~L} / \mathrm{min}$ per person; $\mathrm{ACH}_{\mathrm{SS} 46}$ : ventilation estimate by steady state $\mathrm{CO}_{2}$ level with $\mathrm{CO}_{2}$ generation at $0.46 \mathrm{~L} / \mathrm{min}$ per person; $\mathrm{ACH} \mathrm{H}_{\mathrm{DI}}$ : ventilation rate estimate by $\mathrm{CO} 2$ decay constants using dry ice; $\mathrm{ACH}_{\mathrm{Bv}}$ : ventilation rate estimate by $\mathrm{CO}_{2}$ decay constants using baking soda and vinegar; $\mathrm{ACH}_{\mathrm{Dl} 63}$ : ventilation rate estimate by time needed to remove $63 \%$ excess $\mathrm{CO}_{2}$ by dry ice; $\mathrm{ACH}_{\mathrm{Bv} 63}$ : ventilation rate estimate by time needed to remove $63 \%$ excess $\mathrm{CO}_{2}$ by baking soda and vinegar 
Table 4: Ventilation rate estimates by time needed to remove $63 \%$ excess $\mathrm{CO}_{2}$ released by dry ice or baking soda and vinegar

\begin{tabular}{|c|c|c|c|c|c|c|c|}
\hline RM\# & Method & $\begin{array}{c}C_{R} \\
p p m\end{array}$ & $\begin{array}{c}\mathrm{C}_{\mathrm{s}} \\
\mathrm{ppm}\end{array}$ & $\begin{array}{c}C_{E} \\
\text { ppm }\end{array}$ & $\begin{array}{c}\mathrm{C}_{63 \% \mathrm{E}} \\
\mathrm{ppm}\end{array}$ & $\begin{array}{c}t_{2} \\
\min \end{array}$ & $\begin{array}{c}\mathrm{ACH}_{\mathrm{T} 63 \%} \\
60 / \mathrm{t}_{2}\end{array}$ \\
\hline \multirow[b]{2}{*}{002} & $\mathrm{DI}$ & 403 & 3956 & 3553 & 1718 & 10.7 & 5.6 \\
\hline & BV & 410 & 2800 & 2390 & 1294 & 9.9 & 6.1 \\
\hline \multirow[b]{2}{*}{003} & $\mathrm{DI}$ & 416 & 3552 & 3136 & 1576 & 12.3 & 4.9 \\
\hline & BV & 412 & 1901 & 1489 & 963 & 12.3 & 4.9 \\
\hline \multirow[b]{2}{*}{008} & $\mathrm{DI}$ & 434 & 2459 & 2025 & 1183 & 9.0 & 6.7 \\
\hline & BV & 399 & 2290 & 1891 & 1099 & 8.8 & 6.8 \\
\hline \multirow[b]{2}{*}{012} & DI & 427 & 3064 & 2637 & 1403 & 6.5 & 9.2 \\
\hline & BV & 410 & 2340 & 1930 & 1124 & 6.4 & 9.4 \\
\hline \multirow[b]{2}{*}{019} & $\mathrm{DI}$ & 434 & 2901 & 2467 & 1347 & 2.0 & 30.8 \\
\hline & BV & 399 & 1112 & 713 & 663 & 2.2 & 27.3 \\
\hline \multirow[b]{2}{*}{021} & $\mathrm{DI}$ & 434 & 4265 & 3831 & 1852 & 13.5 & 4.4 \\
\hline & BV & 410 & 1782 & 1372 & 917 & 10.6 & 5.7 \\
\hline \multirow[b]{2}{*}{022} & $\mathrm{DI}$ & 427 & 4103 & 3676 & 1787 & 14.7 & 4.1 \\
\hline & BV & 399 & 2474 & 2075 & 1167 & 13.0 & 4.6 \\
\hline \multirow[b]{2}{*}{031} & $\mathrm{DI}$ & 427 & 2066 & 1639 & 1033 & 3.5 & 17.2 \\
\hline & BV & 416 & 2006 & 1590 & 1004 & 3.6 & 16.7 \\
\hline \multirow[b]{2}{*}{032} & DI & 427 & 2703 & 2276 & 1269 & 3.5 & 17.3 \\
\hline & BV & 410 & 2139 & 1729 & 1049 & 2.7 & 22.2 \\
\hline \multirow[b]{2}{*}{033} & $\mathrm{DI}$ & 434 & 2530 & 2096 & 1210 & 4.2 & 14.3 \\
\hline & BV & 432 & 1291 & 859 & 750 & 3.7 & 16.2 \\
\hline
\end{tabular}

DI: dry ice. BV: baking soda and vinegar. $\mathrm{C}_{\mathrm{R}}$ : outdoor $\mathrm{CO}_{2}$ level. $\mathrm{C}_{s}$ : peak $\mathrm{CO}_{2}$ level after $\mathrm{CO}_{2}$ generation by dry ice or baking soda. $\mathrm{C}_{\mathrm{E}}$ : excess $\mathrm{CO}_{2}$ generated by dry ice or baking soda $\left(\mathrm{C}_{\mathrm{S}}-\mathrm{C}_{\mathrm{R}}\right)$. $\mathrm{C}_{63 \% \mathrm{E}}: \mathrm{CO}_{2}$ level after $63 \%$ excess $\mathrm{CO}_{2}$ is removed $\left(\mathrm{C}_{\mathrm{S}}-63 \% \mathrm{C}_{\mathrm{E}}\right)$. $\mathrm{t}_{2}$ : time $(\mathrm{min})$ needed to reach $\mathrm{C}_{63} \mathrm{E}$. $\mathrm{ACH}_{\mathrm{T} 63 \%}$ : ventilation rate in air change per air based on $t_{2}$ 


\section{Supplemental materials:}

Using steady state $\mathrm{CO}_{2}$ level during dental treatments to estimate ventilation rates: The following table could be used to roughly estimate the ventilation rate of the dental treatment rooms in 3 steps. First, measure the length and width of the room to get the area in square feet $\left(\mathrm{ft}^{2}\right)$. Second, determine the steady state $\mathrm{CO}_{2}$ level during a dental treatment procedure that lasts more than 10 minutes as follows: with the dentist, dental assistant and the patient together in the room and without any person entering or leaving the room, read the $\mathrm{CO}_{2}$ sensor readings 10 minutes into the procedure and record the next 5 readings at $1 \mathrm{~min}$ interval, add the 5 readings to get the sum and divide the sum by 5 , the result is the steady state $\mathrm{CO}_{2}$ level. Third, match the steady state $\mathrm{CO}_{2}$ level to the closest number under the area column of your room size, the number in the $\mathrm{ACH}$ column in the same row is the ventilation rate estimate. For example, if the $\mathrm{CO}_{2}$ level reaches a steady state level of about $1062 \mathrm{ppm}$ during a dental treatment that lasted longer than 5 minutes with 3 persons in a room that is $110 \mathrm{ft}^{2}(10-\mathrm{ft} \mathrm{W} \times 11$ $\mathrm{ft} L$ ) in area, the ventilation rate is about $3 \mathrm{ACH}$. It will be about $6 \mathrm{ACH}$ if the $\mathrm{CO}_{2}$ level stays at about 761 ppm (Supplemental Table 1).

Supplemental Table 1: Steady state $\mathrm{CO}_{2}$ levels and ventilation rate in air change per hour $(\mathrm{ACH})^{*}$

\begin{tabular}{lrrrrrrrrrrr}
$\begin{array}{l}\text { Area } \\
\left(\mathbf{f t}^{\mathbf{2}}\right)\end{array}$ & $\mathbf{1 0 0}$ & $\mathbf{1 1 0}$ & $\mathbf{1 2 0}$ & $\mathbf{1 3 0}$ & $\mathbf{1 4 0}$ & $\mathbf{1 5 0}$ & $\mathbf{1 6 0}$ & $\mathbf{1 7 0}$ & $\mathbf{1 8 0}$ & $\mathbf{1 9 0}$ & $\mathbf{2 0 0}$ \\
$\mathbf{A C H}$ & & & & & & & & & & & \\
\hline $\mathbf{1}$ & 2784 & 2567 & 2386 & 2234 & 2103 & 1989 & 1890 & 1802 & 1724 & 1655 & 1592 \\
\hline $\mathbf{2}$ & 1592 & 1484 & 1393 & 1317 & 1251 & 1195 & 1145 & 1101 & 1062 & 1027 & 996 \\
\hline $\mathbf{3}$ & 1195 & 1122 & 1062 & 1011 & 968 & 930 & 897 & 867 & 841 & 818 & 797 \\
\hline $\mathbf{4}$ & 996 & 942 & 897 & 858 & 826 & 797 & 772 & 751 & 731 & 714 & 698 \\
\hline $\mathbf{5}$ & 877 & 833 & 797 & 767 & 741 & 718 & 698 & 680 & 665 & 651 & 638 \\
\hline $\mathbf{6}$ & 797 & 761 & 731 & 706 & 684 & 665 & 648 & 634 & 621 & 609 & 599 \\
\hline $\mathbf{7}$ & 741 & 710 & 684 & 662 & 643 & 627 & 613 & 600 & 589 & 579 & 570 \\
\hline $\mathbf{8}$ & 698 & 671 & 648 & 629 & 613 & 599 & 586 & 575 & 566 & 557 & 549 \\
\hline $\mathbf{9}$ & 665 & 641 & 621 & 604 & 589 & 577 & 566 & 556 & 547 & 539 & 532 \\
\hline $\mathbf{1 0}$ & 638 & 617 & 599 & 583 & 570 & 559 & 549 & 540 & 532 & 525 & 519 \\
\hline $\mathbf{1 1}$ & 617 & 597 & 581 & 567 & 555 & 544 & 535 & 527 & 520 & 514 & 508 \\
\hline $\mathbf{1 2}$ & 599 & 581 & 566 & 553 & 542 & 532 & 524 & 517 & 510 & 505 & 499 \\
\hline $\mathbf{1 3}$ & 583 & 567 & 553 & 541 & 531 & 522 & 515 & 508 & 502 & 497 & 492 \\
\hline $\mathbf{1 4}$ & 570 & 555 & 542 & 531 & 522 & 514 & 506 & 500 & 495 & 490 & 485 \\
\hline $\mathbf{1 5}$ & 559 & 544 & 532 & 522 & 514 & 506 & 499 & 493 & 488 & 484 & 479 \\
\hline
\end{tabular}

* Based on ventilation rate $\mathrm{ACH}=6 \times 10^{4} \mathrm{n} \mathrm{GP}_{\mathrm{P}} /\left[\mathrm{V}\left(\mathrm{C}_{\mathrm{ss}}-\mathrm{C}_{\mathrm{R}}\right)\right]$, where number of persons in the room $\mathrm{n}=3, \mathrm{CO}_{2}$ generation rate per person $\mathrm{G}_{\mathrm{p}}=0.3 \mathrm{~L} / \mathrm{min}$, outdoor $\mathrm{CO}_{2}$ level $\mathrm{C}_{\mathrm{R}}=400 \mathrm{ppm}$, and $\mathrm{V}$ is the volumetric size of the room with ceiling height $=8$ - $\mathrm{ft}$. 
medRxiv preprint doi: https://doi.org/10.1101/2021.02.04.21251153; this version posted February 8, 2021. The copyright holder for this preprint (which was not certified by peer review) is the author/funder, who has granted medRxiv a license to display the preprint in perpetuity.

All rights reserved. No reuse allowed without permission.

\section{Calculating ventilation rate using $\mathrm{CO}_{2}$ level change after mixing baking soda and vinegar:}

Supplemental Table 2 is a dynamic template that will allow you to enter 3 values to get the ventilation rate in air change per hour $(\mathrm{ACH})$ for your treatment rooms: 1 , the peak $\mathrm{CO}_{2}$ level $\left(C_{s}\right), 2$, the outdoor $\mathrm{CO}_{2}$ level, and 3 . Time needed to reach $63 \%$ removal of excess $\mathrm{CO}_{2}$.

Supplemental Table 2: Ventilation rate estimate using time needed to remove $63 \%$ excess $\mathrm{CO}_{2}$ generated by baking soda and vinegar

\begin{tabular}{|l|r|l|l|}
\hline $\mathrm{CO}_{2}$ at peak & 2800 & $\mathrm{ppm}$ & B1. Cs $=$ Peak CO 2 level Cs \\
\hline $\mathrm{CO}_{2}$ outdoors & 400 & $\mathrm{ppm}$ & B2. CR $=$ Outdoor $\mathrm{CO}_{2}$ level $\mathrm{C}_{R}$ \\
\hline Excess $\mathrm{CO}_{2}$ & 2400 & $\mathrm{ppm}$ & B3. CE $=$ Excess CO $2 . \mathrm{CE}_{\mathrm{E}}=\mathrm{Cs}-\mathrm{C}$ \\
\hline After removal of $63 \%$ excess CO 2 & 1288 & $\mathrm{ppm}$ & B4. C63\% $=\mathrm{CO}_{2}$ level after remova \\
\hline Time needed to remove $63 \%$ excess CO 2 & 15.0 & $\mathrm{~min}$ & B5. Time to reach C63\% (Value in \\
\hline Ventilation rate & 4.0 & $\mathrm{~h}^{-1}$ & B6. Air change per hour, or ACH \\
\hline
\end{tabular}

To calculate air change per hour, 3 values need to be entered into the above template:

1. Cs: this is the $\mathrm{CO}_{2}$ level when the measurement starts after $\mathrm{CO}_{2}$ generation by mixing baking soda and vines

2. Outdoor $\mathrm{CO}_{2}$ level. You could use $400 \mathrm{ppm}$ as an estimate for this value.

3. Time needed to reach $63 \%$ removal of excess $\mathrm{CO}_{2}$.

You need to read the value in $\mathrm{B} 5$ and check the $\mathrm{CO}_{2}$ sensor readings to get the time needed to reach $63 \%$ rem

\section{References:}

1. S. Batterman, Review and Extension of $\mathrm{CO}_{2}$-Based Methods to Determine Ventilation Rates with Application to School Classrooms, Int J Environ Res Public Health 14(2) (2017).

2. J.-L. Jimenez, How to quantify the ventilation rate of an indoor space using an affordable $\mathrm{CO} 2$ monitor, Medium, 2020. Available at: https://medium.com/@jjose 19945/how-to-quantify-theventilation-rate-of-an-indoor-space-using-a-cheap-co2-monitor-4d8b6d4dab44

3. A. Fernstrom, M. Goldblatt, Aerobiology and its role in the transmission of infectious diseases, J Pathog 2013 (2013) 493960-493960.

4. E.A. Nardell, J. Keegan, S.A. Cheney, S.C. Etkind, Airborne infection. Theoretical limits of protection achievable by building ventilation, Am Rev Respir Dis 144(2) (1991) 302-6. 
medRxiv preprint doi: https://doi.org/10.1101/2021.02.04.21251153; this version posted February 8, 2021. The copyright holder for this preprint (which was not certified by peer review) is the author/funder, who has granted medRxiv a license to display the preprint in perpetuity. All rights reserved. No reuse allowed without permission.

\section{References:}

[1] CDC, How COVID-19 spreads, 2020. https://www.cdc.gov/coronavirus/2019-ncov/preventgetting-sick/how-covid-spreads.html. (Accessed Feb. 4 2021).

[2] CDC, Scientific Brief: SARS-CoV-2 and Potential Airborne Transmission, 2020.

https://www.cdc.gov/coronavirus/2019-ncov/more/scientific-brief-sars-cov-2.html. (Accessed Feb. 4 2021).

[3] CDC, Guidance for Dental Settings - Interim Infection Prevention and Control Guidance for Dental Settings During the COVID-19 Pandemic, 2020. https://www.cdc.gov/coronavirus/2019ncov/hcp/dental-settings.html. (Accessed Feb. 4 2021).

[4] C.M. Issarow, N. Mulder, R. Wood, Modelling the risk of airborne infectious disease using exhaled air, J Theor Biol 372 (2015) 100-6.

[5] S. Batterman, Review and Extension of $\mathrm{CO}_{2}$-Based Methods to Determine Ventilation Rates with Application to School Classrooms, Int J Environ Res Public Health 14(2) (2017).

[6] T.A. Myatt, S.L. Johnston, Z. Zuo, M. Wand, T. Kebadze, S. Rudnick, D.K. Milton, Detection of airborne rhinovirus and its relation to outdoor air supply in office environments, Am J Respir Crit Care Med 169(11) (2004) 1187-90.

[7] E.T. Richardson, C.D. Morrow, D.B. Kalil, S. Ginsberg, L.G. Bekker, R. Wood, Shared air: a renewed focus on ventilation for the prevention of tuberculosis transmission, PLoS One 9(5) (2014) e96334.

[8] R. Wood, C. Morrow, S. Ginsberg, E. Piccoli, D. Kalil, A. Sassi, R.P. Walensky, J.R. Andrews, Quantification of Shared Air: A Social and Environmental Determinant of Airborne Disease Transmission, PLOS ONE 9(9) (2014) e106622.

[9] A. Harrichandra, A.M. lerardi, B. Pavilonis, An estimation of airborne SARS-CoV-2 infection transmission risk in New York City nail salons, Toxicol Ind Health 36(9) (2020) 634-643.

[10] S.N. Rudnick, D.K. Milton, Risk of indoor airborne infection transmission estimated from carbon dioxide concentration, Indoor Air 13(3) (2003) 237-45.

[11] C. Zemouri, S.F. Awad, C.M.C. Volgenant, W. Crielaard, A.M.G.A. Laheij, J.J. de Soet, Modeling of the Transmission of Coronaviruses, Measles Virus, Influenza Virus, Mycobacterium tuberculosis, and Legionella pneumophila in Dental Clinics, Journal of Dental Research 99(10) (2020) 1192-1198.

[12] A. STANDARD, Ventilation for Acceptable Indoor Air Quality. ANSI/ASHRAE Standard 62.12007., 2007, pp. 1-48.

[13] C.C. Godwin, S.A. Batterman, S.P. Sahni, C.Y. Peng, Indoor environment quality in dental clinics: potential concerns from particulate matter, Am J Dent 16(4) (2003) 260-6.

[14] C.G. Helmis, J. Tzoutzas, H.A. Flocas, C.H. Halios, V.D. Assimakopoulos, O.I. Stathopoulou, V. Panis, M. Apostolatou, Emissions of total volatile organic compounds and indoor environment assessment in dental clinics in Athens, Greece, Int Dent J 58(5) (2008) 269-78.

[15] C.G. Helmis, J. Tzoutzas, H.A. Flocas, C.H. Halios, O.I. Stathopoulou, V.D. Assimakopoulos, V. Panis, M. Apostolatou, G. Sgouros, E. Adam, Indoor air quality in a dentistry clinic, Sci Total Environ 377(2-3) (2007) 349-65.

[16] ASHRAE, ASHRAE/ANSI Standard 111- 2008 (RA 2017) Measurement, Testing, Adjusting and Balancing of Building HVAC Systems., ASHRAE, Atlanta, GA. , 2017. 
medRxiv preprint doi: https://doi.org/10.1101/2021.02.04.21251153; this version posted February 8, 2021. The copyright holder for this preprint (which was not certified by peer review) is the author/funder, who has granted medRxiv a license to display the preprint in perpetuity.

All rights reserved. No reuse allowed without permission.

[17] Y.-F. Ren, Q. Huang, T. Marzouk, R. Richard, K. Pembroke, P. Martone, T. Venner, H. Malmstrom, E. Eliav, Effects of mechanical ventilation and portable air cleaner on aerosol removal from dental treatment rooms, Journal of Dentistry 105 (2021) 103576.

[18] Institutional Consultation Services, What does air change mean?, Isolation Rooms: Design, Assessment, and Upgrade. , Francis J Curry National Tuberculosis Center, 1999, pp. 43-44.

[19] A. Persily, L. de Jonge, Carbon dioxide generation rates for building occupants, Indoor Air 27(5) (2017) 868-879.

[20] M.W. Qi, X.F. Li, L.B. Weschler, J. Sundell, CO2 generation rate in Chinese people, Indoor Air 24(6) (2014) 559-66.

[21] REHVA - Federation of European Heating Ventilation and Air Conditioning Associations, How to operate HVAC and other building service systems to prevent the spread of the coronavirus disease (COVID-19) in workplaces, 2020, p. 42.

[22] J.-L. Jimenez, How to quantify the ventilation rate of an indoor space using an affordable CO2 monitor, 2020. https://medium.com/@jjose_19945/how-to-quantify-the-ventilation-rateof-an-indoor-space-using-a-cheap-co2-monitor-4d8b6d4dab44.

[23] A. Fernstrom, M. Goldblatt, Aerobiology and its role in the transmission of infectious diseases, J Pathog 2013 (2013) 493960-493960.

[24] E.A. Nardell, J. Keegan, S.A. Cheney, S.C. Etkind, Airborne infection. Theoretical limits of protection achievable by building ventilation, Am Rev Respir Dis 144(2) (1991) 302-6.

[25] K. Azuma, N. Kagi, U. Yanagi, H. Osawa, Effects of low-level inhalation exposure to carbon dioxide in indoor environments: A short review on human health and psychomotor performance, Environment International 121 (2018) 51-56.

[26] P. Fabian, J.J. McDevitt, W.M. Lee, E.A. Houseman, D.K. Milton, An optimized method to detect influenza virus and human rhinovirus from exhaled breath and the airborne environment, J Environ Monit 11(2) (2009) 314-7.

[27] W.G. Lindsley, F.M. Blachere, D.H. Beezhold, R.E. Thewlis, B. Noorbakhsh, S. Othumpangat, W.T. Goldsmith, C.M. McMillen, M.E. Andrew, C.N. Burrell, J.D. Noti, Viable influenza A virus in airborne particles expelled during coughs versus exhalations, Influenza Other Respir Viruses 10(5) (2016) 404-13.

[28] L. Yip, M. Finn, A. Granados, K. Prost, A. McGeer, J.B. Gubbay, J. Scott, S. Mubareka, Influenza virus RNA recovered from droplets and droplet nuclei emitted by adults in an acute care setting, J Occup Environ Hyg 16(5) (2019) 341-348.

[29] H. Qian, T. Miao, L. Liu, X. Zheng, D. Luo, Y. Li, Indoor transmission of SARS-CoV-2, Indoor Air (2020).

[30] R.Y.W. Chinn, L. Sehulster, Guidelines for environmental infection control in health-care facilities; recommendations of CDC and Healthcare Infection Control Practices Advisory Committee (HICPAC), (2003).

[31] P. Ninomura, J. Bartley, New Ventilation Guidelines for Health-Care Facilities, ASHRAE Journal, 43(6) (2001) 29-32.

[32] M.H. Sherman, N. Matson, Residential ventilation and energy characteristics., ASHRAE Trans. 103 (1997) 717-730.

[33] P.L. Cheng, X. Li, Air Change Rate Measurements using Tracer Gas Carbon Dioxide from Dry Ice, International Journal of Ventilation 13(3) (2014) 235-246. 
medRxiv preprint doi: https://doi.org/10.1101/2021.02.04.21251153; this version posted February 8, 2021. The copyright holder for this preprint (which was not certified by peer review) is the author/funder, who has granted medRxiv a license to display the preprint in perpetuity.

All rights reserved. No reuse allowed without permission.

[34] R. Stuart, E. Sweet, A. Batchelder, Assessing general ventilation effectiveness in the laboratory, Journal of Chemical Health \& Safety 22(2) (2015) 2-7.

[35] R. Claude-Alain, F. Foradini, Simple and Cheap Air Change Rate Measurement Using CO2 Concentration Decays, International Journal of Ventilation 1(1) (2002) 39-44.

[36] L. Morawska, D.K. Milton, It Is Time to Address Airborne Transmission of Coronavirus Disease 2019 (COVID-19), Clin Infect Dis 71(9) (2020) 2311-2313.

[37] Z. Noorimotlagh, N. Jaafarzadeh, S.S. Martínez, S.A. Mirzaee, A systematic review of possible airborne transmission of the COVID-19 virus (SARS-CoV-2) in the indoor air environment, Environ Res 193 (2020) 110612.

[38] R. Zhang, Y. Li, A.L. Zhang, Y. Wang, M.J. Molina, Identifying airborne transmission as the dominant route for the spread of COVID-19, Proc Natl Acad Sci U S A 117(26) (2020) 1485714863.

[39] J.A. Harte, Standard and transmission-based precautions: an update for dentistry, J Am Dent Assoc 141(5) (2010) 572-81.

[40] P. Xu, E. Kujundzic, J. Peccia, M.P. Schafer, G. Moss, M. Hernandez, S.L. Miller, Impact of Environmental Factors on Efficacy of Upper-Room Air Ultraviolet Germicidal Irradiation for Inactivating Airborne Mycobacteria, Environmental Science \& Technology 39(24) (2005) 96569664.

[41] P. Xu, J. Peccia, P. Fabian, J.W. Martyny, K.P. Fennelly, M. Hernandez, S.L. Miller, Efficacy of ultraviolet germicidal irradiation of upper-room air in inactivating airborne bacterial spores and mycobacteria in full-scale studies, Atmospheric Environment 37(3) (2003) 405-419.

[42] G. Ko, M.W. First, H.A. Burge, The characterization of upper-room ultraviolet germicidal irradiation in inactivating airborne microorganisms, Environmental Health Perspectives 110(1) (2002) 95-101. 